\title{
The differences in milkability, milk, and health traits in dairy cattle due to parity
}

\author{
doi: 10.15567/mljekarstvo.2018.0107 \\ Tina Bobić ${ }^{1}$, Pero Mijić1 , Maja Gregić ${ }^{1}$, Vesna Gantner ${ }^{2}$ \\ ${ }^{1}$ University of Josip Juraj Strossmayer in Osijek, Faculty of Agriculture in Osijek, \\ Department for animal breeding, Vladimira Preloga 1, 31000 Osijek, Osijek, Croatia \\ ${ }^{2}$ University of Josip Juraj Strossmayer in Osijek, Faculty of Agriculture in Osijek, \\ Department for special zootechnique, Vladimira Preloga 1, 31000 Osijek, Osijek, Croatia
}

Received - Prispjelo: 29.03.2017.

Accepted - Prihvaćeno: 17.12.2017.

\begin{abstract}
The aim of this study was to determine the differences in milkability, milk and health traits in Holstein and Simmental dairy cattle due to parity. Following traits were analysed: milkability (duration of milking, MT; milk yield per milking, MYM; maximal, MMF and average milk flow, AMF), milk traits (daily milk yield, DMY; daily fat content, DFC; daily protein content, DPC; daily lactose content, DLC; urea, UREA) and health traits (logarithmic somatic cell count, SCClog and teatend hyperkeratosis, TEH). Significant $(\mathrm{p}<0.05 ; \mathrm{p}<0.01 ; \mathrm{p}<0.0001)$ differences between parity in MYM, DMY, MMF, DPC and DLC was determined. Also, significant $(\mathrm{p}<0.0001)$ difference in the teat-end hyperkeratosis score were found between cows in $1^{\text {st }}$ and $2^{\text {nd }}$ as well as between cows in $1^{\text {st }}$ and $\geq 3^{\text {rd }}$ parity. The cows in $1^{\text {st }}$ and $2^{\text {nd }}$ parity had similar SCClog, while significant $(\mathrm{p}<0.05)$ difference was found between SCClog in cows in $1^{\text {st }}$ and cows in $\geq 3^{\text {rd }}$ parity. The obtained results indicate that the parity significantly affect the milkability, milk and health traits. Since the hyperkeratosis level is highly correlated to the mastitis incidence risk, the regular teat-end scoring should be used in order to ensure quality machine milking and to minimize mastitis incidence risk.
\end{abstract}

Key words: parity, milk yield and composition, milkability, teat-end hyperkeratosis, somatic cell count, dairy cattle

\section{Introduction}

Duration and characteristics of machine milking depend on the udder and teat conformation, as well as on cows' production and milkability traits. According to Interbull (1999) the health of udder is one of the most important issues in dairy cattle selection. The conformation of the udder (Rupp and Boichard, 1999; Coban et al., 2009), characteristics of the teats (Chrystal et al., 1999; Amin et al., 2002; Rensing and Ruten, 2006) and the teat-end shape (Hodghson and Murdock, 1980; Lojda et al., 1982, Neijenhuis et al., 2000) affect the proper milking and risk of the mastitis. Teat-end is an important first line of defence in protecting of the udder from the invasion of mastitis pathogens (Stádník et al., 2010). Furthermore, the changes in teat tissue due to milking may reduce the effectiveness of the teat canal barrier against infections (Neijenhuis et al., 2000). Guler et al. (2009) stated that the milkability traits as functional traits have important role in machine milking of dairy cows. The most important milkability traits are average and maximal milk flow, as well as the duration of milking (Gäde et al., 2006). In order to ensure quality milking, milking of cows needs to be fast, clean, gentle and complete. Zecconi et al. (1992) emphased that machine milking should not cause more than $5 \%$ of 
the thickening or thinning of the teat tissue. Furthermore, Neijen huis (2004) stated that the mechanical forces during machine milking result in changes in teat-end tissue. One of such changes is teat-end hyperkeratosis (TEH) which means excessive keratin growth, caused by the mechanical pressure of teat cup liner, inadequate hygiene and protection of teats after milking, conformation of the udder and teats, season, microclimate condition etc. (Hillerton et al., 2000; Mein et al., 2003, Ohnstad, 2003; Mein and Reinemann, 2009). According to Neijenhuis et al. (2001) and de Pinho et al. (2012) increase of the teat-end callosity thickness or teat-end callosity roughness increases the incidence risk of clinical mastitis. The researches of Gleeson et al. (2004) and Haghkhah et al. (2011) confirmed a significant positive correlation between teat condition and somatic cell count (SCC). They also reported that injured teat had significantly higher SCC in comparison to normal teat. Furthermore, Singh et al. (2014) determined significantly higher $\mathrm{SCC}_{\log }$ in dairy bovines with discoloured teat skin, cracked and with very rough teat ends in comparison to dairy bovines with teats with normal skin and smooth teat ends. Neijenhuis et al. (2001) and Neijenhuis (2004) emphasised that teat condition scoring could be used as a valuable and uncostly tool for milking machine optimization. Quick and proper detection of the cause of poor teat condition would reduce somatic cell counts and clinical mastitis prevalence, and consequently it will save time and treatment costs (Taylor, 2006). The objective of this study was to determine the differences in milkability, milk and health traits in Holstein and Simmental dairy cattle due to parity.

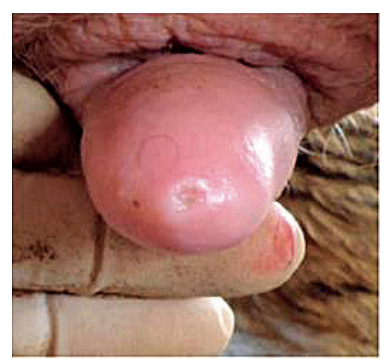

Score 1

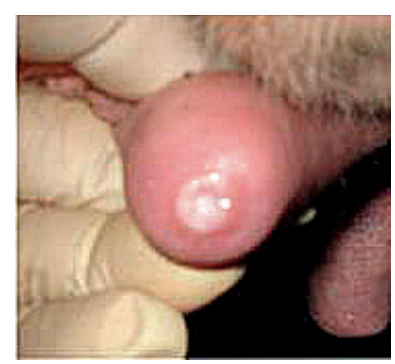

Score 2

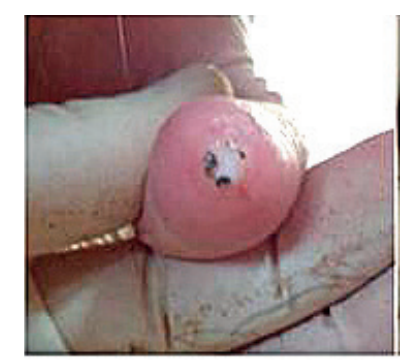

Score 3

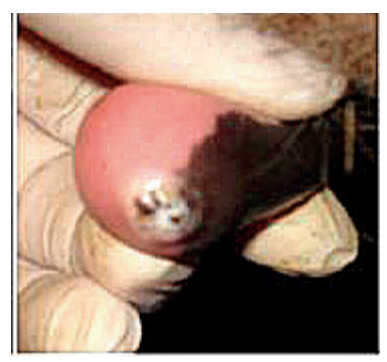

Score 4

(score 1 - without callous (keratin ring); score 2 - formed and clearly visible callous; score 3 - rough callous with hyperkeratosis; score 4 - very rough hyperkeratosis and radial cracking)

Figure 1. The score for the teat-end hyperkeratosis 
Logical control of milk data was performed according to ICAR standards (2003). Somatic cell count was transformed on a log scale. Statistical analysis was performed by a StatSoft Statistica 8 (2008). The effect of parity $(1 ; 2$ and $\geq 3$ ) on the milkability, milk and health traits was determined by the One - Way ANOVA and significance of differences was tested with Fisher LSD test $(p<0.0001)$.

\section{Results and discussion}

Variability of the analysed traits is presented on Table 1. Milk yield per milking ranged from 5.15 to $21.88 \mathrm{~kg}$ with mean production $10.68 \mathrm{~kg}$ per milking, while daily milk yield ranged from 10.20 to $48.20 \mathrm{~kg}$ with mean daily production $23.53 \mathrm{~kg}$. Higher MYM in amount of $14.14 \mathrm{~kg}$ and $12.40 \mathrm{~kg}$ were measured in research of Lee and Choudhary (2006) and Gäde et al. (2006), while the Mijić et al. (2004) determined lower MYM $(8.03 \mathrm{~kg})$. The minimum daily milk fat and daily protein contents were 2.02 and $2.37 \%$, while the maximum values were 6.08 and $4.38 \%$. The Simmental cows investigated by Mijić et al. (2004) had higher minimum $(2.49 ; 2.87 \%)$ but similar maximum $(5.76 ; 4.41 \%)$ values of DFC and DPC. Mean urea content was $28.61 \mathrm{mg} / 100 \mathrm{~mL}$, while mean daily lactose content was $4.47 \%$. Mean maximal milk flow was $3.07 \mathrm{~kg} / \mathrm{min}$, while mean average milk flow was $1.97 \mathrm{~kg} / \mathrm{min}$. Higher values for MMF and AMF comparing to this research in amount of 3.21 and $2.30 \mathrm{~kg} / \mathrm{min}$ were determined by Lee and Choudhary (2006). Duration of milking ranged from 2.52 to $13.22 \mathrm{~min}$, with mean value $7.73 \mathrm{~min}$. Higher mean duration of milking was determined in research conducted by Davis and Reinemann (2002).

Transformed somatic cell count $\left(\mathrm{SCC}_{\log }\right)$ ranged from -0.64 to 5.81 , with mean value at 2.80 . Higher average values of $\mathrm{SCC}_{\log }$ were determined in studies by Davis and Reinemann (2002) and Coban et al. (2009). Average score of teat-end hyperkeratosis was 1.71 .

The results of variance analyses are presented in Table 2. The effect of parity on milk yield per milking and maximum milk flow was significant $(p<0.05 ; p<0.01)$. The cows in first parity had significantly $(\mathrm{p}<0.05)$ lower milk yield per milking (9.57 kg) comparing to cows in second (12.56 kg) and third and other parities $(11.80 \mathrm{~kg})$. These results were consistent with the results of Tančin et al. (2006). Maximum milk flow in the first parity cow's was significantly $(\mathrm{p}<0.01)$ lower $(2.68 \mathrm{~kg} / \mathrm{min})$ compering to cows in $\geq 3$ parity $(3.50 \mathrm{~kg} / \mathrm{min})$. Significant effect of parity on average milk flow, maximum milk flow and milking time was also confirmed in research of Gäde et al. (2006) and Guler et al. (2009).

Table 1. Descriptive statistic for analysed traits

\begin{tabular}{|c|c|c|c|c|c|c|c|}
\hline & Traits & Mean & Min & Max & SD & $\mathrm{CV}$ & SE \\
\hline \multirow{4}{*}{ 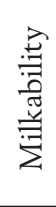 } & MYM, kg & 10.68 & 5.15 & 21.88 & 4.14 & 38.73 & 0.34 \\
\hline & $\mathrm{MMF}, \mathrm{kg} / \mathrm{min}$ & 3.07 & 1.15 & 6.57 & 1.15 & 37.35 & 0.09 \\
\hline & $\mathrm{AMF}, \mathrm{kg} / \mathrm{min}$ & 1.97 & 0.56 & 3.47 & 0.68 & 34.59 & 0.06 \\
\hline & MT, min & 7.73 & 2.52 & 13.22 & 2.86 & 37.05 & 0.23 \\
\hline \multirow{5}{*}{ 总 } & DMY, kg/day & 23.53 & 10.20 & 48.20 & 9.96 & 42.31 & 0.81 \\
\hline & DFC, $\%$ & 3.72 & 2.02 & 6.08 & 0.85 & 22.83 & 0.07 \\
\hline & DPC, $\%$ & 3.37 & 2.37 & 4.38 & 0.35 & 10.48 & 0.03 \\
\hline & DLC, $\%$ & 4.47 & 3.94 & 4.85 & 0.18 & 4.09 & 0.01 \\
\hline & UREA, mg/100 mL & 28.61 & 2.80 & 67.00 & 12.02 & 42.02 & 0.98 \\
\hline \multirow{2}{*}{ 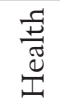 } & $\mathrm{SCC}_{\log }$ & 2.80 & -0.64 & 5.81 & 1.30 & 46.44 & 0.11 \\
\hline & TEH & 1.71 & 1.00 & 4.00 & 0.79 & 46.43 & 0.06 \\
\hline
\end{tabular}

MYM - milk yield per milking; MMF - maximal milk flow; AMF - average milk flow; MT - duration of milking;

DMY - daily milk yield; DFC - daily fat content; DPC - daily protein content, DLC - daily lactose content; UREA - urea;

SCClog - somatic cell count on log scale; TEH - teat-end hyperkeratosis 
The significant difference in MYM and MMF among cows in 2 and $\geq 3$ parity was not determined. The average milk flow and duration of milking did not differ significantly in cows depending on the parity, which is different from results obtained by Gäde et al. (2006). The values of the MYM, MMF and AMF increased in successive parities which is in accordance with results determined by Roth et al. (1998) but in contrast with Naumann (2001). Cows in the first parity had significantly $(\mathrm{p}<0.0001)$ lower average daily milk yield (19.18 kg/day) comparing to cows in the 2 and $\geq 3$ parities (32.01; $26.68 \mathrm{~kg}$ /day), which was confirmed in previous researches too (Aydin et al., 2008; Guler et al., 2009). Also, significant differences $(\mathrm{p}<0.05$; $\mathrm{p}<0.01$ ) were found in DPC and DLC. Daily protein content was higher in cows in the first parity ( $3.52 \%)$ comparing to cows in the second, third and other parities $(3.27 \%, 3.34 \%)$. Cows in the 1 and 2 parity had significantly $(\mathrm{p}<0.01)$ higher daily lactose content ( $4.52 \% ; 4.50 \%)$ comparing to cows in the $\geq 3$ parities $(4.39 \%)$.

Figures 2 and 3 present the differences among the health traits (TEH and $\mathrm{SCC}_{\log }$ ) in cows regarding the parity. The score of the teat-end hyperkeratosis is positively correlated with the parity. There is highly significant $(\mathrm{p}<0.0001)$ difference between TEH score in the cows in first and second (1.33; 1.79) parities as well as between the cows in first and third and other parities $(1.33 ; 1.89)$. Neijenhuis et al.
(2001) as well as de Pinho et al. (2012) emphases that increase of teat-end callosity thickness or teatend callosity roughness increases the incidence risk of clinical mastitis. Furthermore, Haghkhah et al. (2011) determined significant correlation between teat condition and SCC. Same authors also reported that the cows with injured teats have significantly higher SCC in comparison to the cows with normal teats.

Somatic cell count is the most frequently used indicator of cow's health (subclinical mastitis) and milk quality in dairy cattle breeding (Tsenkova et al., 2001). Regarding the variability of the somatic cell count in this research (Figure 3), cows in first and second parities had similar $\mathrm{SCC}_{\log }$ values, while significant $(\mathrm{p}<0.05)$ difference was found in $\mathrm{SCC}_{\log }$ between the cows in first parity (2.49) and the cows in third and other parities (3.14).

According to Neijenhuis et al. (2004) the incidence risk (IR) of mastitis increases with parity, therefore the cows in first lactation had the lowest IR comparing to those in second and later lactations. Furthermore, Singh et al. (2014) determined significantly higher $\mathrm{SCC}_{\log }$ (implying increased incidence risk of mastitis) in dairy bovines with cracked and very rough teat ends in comparison to dairy bovines with teats with smooth teat ends. The effects that cause changes on teat tissue are breed (Bobić et al., 2014), parity, lactation stage and teat conformation (Sieber and Farnsworth, 1981; Neijenhuis

Table 2. ANOVA results for study traits

\begin{tabular}{|c|c|c|c|c|c|c|c|c|}
\hline & \multirow{2}{*}{ Traits } & \multicolumn{2}{|c|}{$\begin{array}{c}\text { Lactation } 1 \\
\quad(n=20)\end{array}$} & \multicolumn{2}{|c|}{$\begin{array}{c}\text { Lactation } 2 \\
(\mathrm{n}=21)\end{array}$} & \multicolumn{2}{|c|}{$\begin{array}{c}\text { Lactation } \geq 3 \\
(n=35)\end{array}$} & \multirow{2}{*}{$\mathrm{p}$} \\
\hline & & Mean & SD & Mean & SD & Mean & SD & \\
\hline \multirow{4}{*}{ 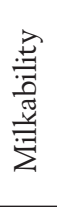 } & MYM & $9.57^{a}$ & 3.15 & $12.56^{\mathrm{b}}$ & 4.34 & $11.80^{\mathrm{bc}}$ & 4.20 & $\mathrm{p}<0.05$ \\
\hline & MMF & $2.68^{\mathrm{a}}$ & 0.68 & $3.26^{\mathrm{ab}}$ & 0.96 & $3.50^{\mathrm{b}}$ & 1.35 & $\mathrm{p}<0.01$ \\
\hline & $\mathrm{AMF}$ & 1.77 & 0.50 & 1.88 & 0.70 & 2.14 & 0.73 & NS \\
\hline & MT & 7.36 & 1.85 & 8.45 & 4.21 & 7.51 & 2.24 & NS \\
\hline \multirow{5}{*}{ 埥 } & DMY & $19.18^{\mathrm{a}}$ & 5.48 & $32.01^{\mathrm{b}}$ & 10.99 & $26.68^{c}$ & 9.40 & $\mathrm{p}<0.0001$ \\
\hline & DFC & 3.97 & 0.70 & 3.51 & 0.98 & 3.81 & 0.86 & NS \\
\hline & DPC & $3.52^{\mathrm{a}}$ & 0.36 & $3.27^{\mathrm{bc}}$ & 0.32 & $3.34^{\mathrm{c}}$ & 0.37 & $\mathrm{p}<0.05$ \\
\hline & DLC & $4.52^{\mathrm{a}}$ & 0.15 & $4.50^{\mathrm{ab}}$ & 0.19 & $4.39^{c}$ & 0.17 & $\mathrm{p}<0.01$ \\
\hline & UREA & 22.90 & 16.41 & 24.74 & 9.12 & 25.66 & 10.02 & NS \\
\hline
\end{tabular}

$\mathrm{p}<0.05 ; \mathrm{p}<0.01 ; \mathrm{p}<0.0001$ - level of significance; abc - values marked with different later are significant; NS - no significant; $\mathrm{n}$ - number of the animals; MYM - milk yield per milking; MMF - maximal milk flow; AMF - average milk flow; MT - duration of milking; DMY - daily milk yield; DFC - daily fat content; DPC - daily protein content, DLC - daily lactose content; UREA - urea 
et al., 2000; Neijenhuis, 2004). Those changes were caused by mechanical pressure of liners and excessive vacuum during the milking (Shearn and Hillerton, 1996; Mein et al., 2003, Mein and Reinemann, 2009). With respect to the above mentioned as well as to the results of the present study, excesskeratin growth (TEH) on teat ends most probably originated from morphological changes of teats occuring due to ageing of cows and frequent repetition of milking, especially the inadequate ones (too high or too low milk flow, excess vacuum, liners of inoperative or inadequate dimensions). Simultaneously with excessive keratin growth and increase of teat-end callosity roughness, somatic cell count increases, the closing of teat canal aggravates and risk of mastitis increases.

\section{Conclusions}

For quality milking, cows need to be milked fast, cleanly, gently and completely. Furthermore, the machine milking should not cause too many changes in teat tissue. The characteristics and duration of machine milking are dependent on the udder and teat conformation, as well as on production and milkability traits of cows. The research results indicate that the parity significantly affect the milkability, milk and health traits. Also, positive relationship between the level of hyperkeratosis and parity was determined. Since the hyperkeratosis level is highly correlated to the mastitis incidence risk, the regular teat-end scoring should be used in order to ensure quality machine milking and to minimize mastitis incidence risk.

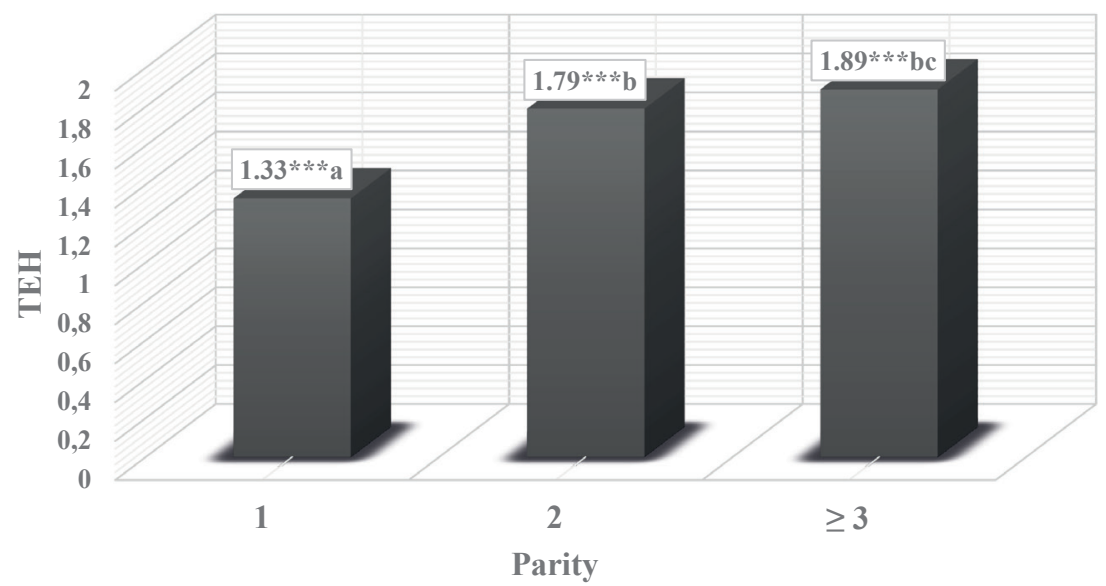

(1 - first lactation; 2 - second lactation; $\geq 3$ - third and later lactations; ${ }^{* * *} \mathrm{p}<0.0001$;

abc - values marked with different later are significant; TEH - teat-end hyperkeratosis)

Figure 2. The results of the teat-end hyperkeratosis score regarding the parity

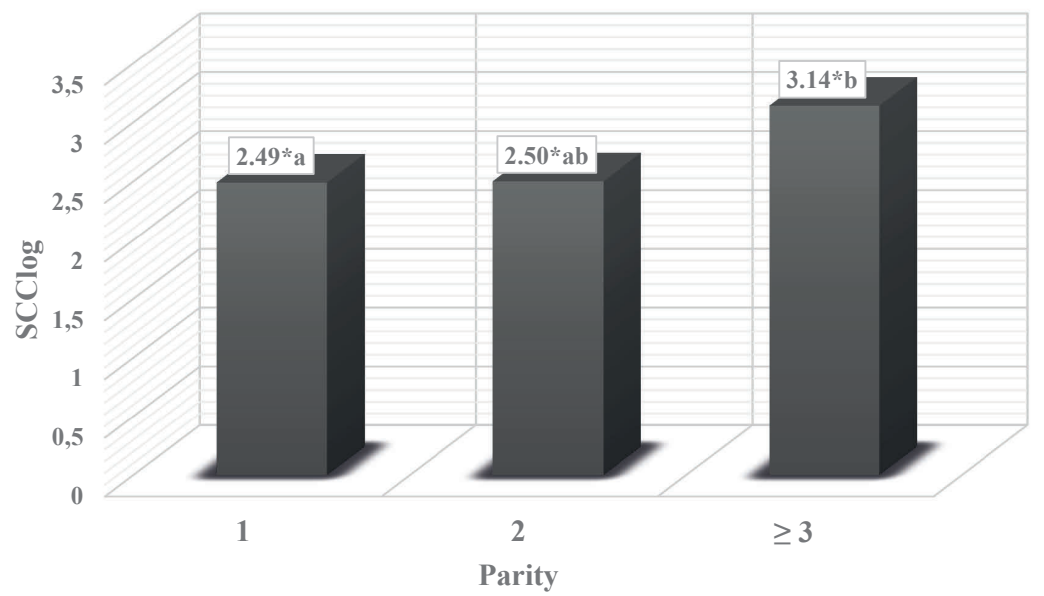

(1 - first lactation; 2 - second lactation; $\geq 3$ - third and later lactations; ${ }^{*} \mathrm{p}<0.05$;

$\mathrm{ab}$ - values marked with different later are significant; $\mathrm{SCC}_{\log }$ - logarithmical transformed somatic cell count)

Figure 3. The results of the somatic cell count regarding the parity 


\section{Različitosti u muznim, mliječnim $i$ zdravstvenim svojstvima kod krava u proizvodnji mlijeka ovisno o rednom broju laktacije}

\section{Sažetak}

Cilj rada bio je utvrditi različitosti u muznim, mliječnim i zdravstvenim svojstvima krava simentalske i holstein pasmine ovisno o rednom broju laktacije. Analizirana su sljedeća svojstva: muzna (trajanje mužnje, MT; količina mlijeka po mužnji, MYM; maksimalni, MMF i prosječni protok mlijeka, AMF), svojstva mlijeka (dnevna količina mlijeka, DMY; dnevna količina masti, DFC; dnevna količina proteina, DPC; dnevna količina laktoze, DLC; urea, UREA) i zdravstvena svojstva (logaritmirani broj somatskih stanica, $\mathrm{SCC}_{\log }$; hiperkeratoza vrhova sisa, TEH). Utvrđen je visoko signifikantan $(\mathrm{p}<0,05 ; \mathrm{p}<0,01 ; \mathrm{p}<0,0001)$ razlika $\mathrm{u}: \mathrm{MYM}$, DMY, MMF, DPC i DLC između svih laktacija. Također je utvrđena visoko značajna $(p<0,0001)$ razlika u hiperkeratozi vrhova sisa između krava u 1 . i 2., te između krava u 1 . i $\geq 3$. laktaciji. Krave u prvoj i drugoj laktaciji imale su približno isti broj $\mathrm{SCC}_{\log }$, međutim značajnost $(\mathrm{p}<0,05)$ je utvrđena između $\mathrm{SCC}_{\log }$ kod krava u prvoj i krava u trećoj i ostalim laktacijama. Rezultati istraživanja ukazuju na to da redni broj laktacije značajno utječe na muzna, svojstva mlijeka i zdravstvena svojstva. Budući da je razina hiperkeratoze jako povezana s rizikom od nastanka mastitisa, potrebno je redovito ocjenjivati vrhove sisa kako bi se osigurala kvalitetna mužnja a ujedno i smanjio rizik od nastanka mastitisa.

Ključne riječi: redoslijed laktacije, količina i sastav mlijeka, muznost, hiperkeratoza vrhova sisa, broj somatskih stanica, krave $\mathrm{u}$ proizvodnji mlijeka

\section{References}

1. Ali, A.K.A., Shook, G.E. (1980): An optimum transformation for somatic cell concentration in milk. Journal of Dairy Science 63, 487-490. https://doi.org/10.3168/jds.S0022-0302(80)82959-6
2. Amin, A.A., Gere, T., Kishk, W.H. (2002): Genetic and environmental relationship among udder conformation traits and mastitis incidence in Holstein Friesian into two different environments. Archiv fur Tierzucht, Dummerstorf 45 (1), 129-138.

3. Aydin, A.R., Yanar, M., Guler, O., Yuksel, S., Ugur, F., Turgut, L. (2008): Study on milkability traits in Brown Swiss cows reared eastern region of Turkey. Journal of Animal and Veterinary Advances 7 (10), 1218-1222.

4. Bobić, T., Mijić, P., Vučković, G., Gregić, M., Baban, M., Gantner, V. (2014): Morphological and milkability breed differences of dairy cows. Mljekarstvo 64 (2), 71-78.

5. Britt, J.S., Farnsworth, R. (2005): Here's a system for evaluating teat condition. Hoard's Dairyman.

6. Coban, O., Sabuncuoglu, N., Tuzemen, N. (2009): A study on relationships between somatic cell count (SCC) and some udder traits in dairy cows. Journal of Animal and Veterinary Advances 8 (1), 134-138.

7. Chrystal, M.A., Seykora, A.J., Hansen, L.B. (1999): Heritabilities of teat end shape and teat diameter and their relationships with somatic cell score. Journal of Dairy Science 82, 2017-2022. https://doi.org/10.3168/jds.S0022-0302(99)75439-1

8. Davis, M.A., Reinemann, D.J. (2002): Milking performance and udder health of cows milked robotically and conventionally. ASAE Annual International Meeting / CIGR XV ${ }^{\text {th }}$ World Congress, Chicago, Illinois, USA July 28-July 31 .

9. de Pinho M.M., Nóbrega, D.B., Faccioli, P.Y., Troncarelli, M.Z., Menozzi, B.D., Langoni, H. (2012): Relationship between teat-end condition, udder cleanliness and bovine subclinical Mastitis. Research in Veterinary Science 93, 430-434. https://doi.org/10.1016/j.rvsc.2011.05.010

10. Dodenhoff, J., Sprengel, D., Duda, J., Dempfle, L. (1999): Zucht auf Eutergesundheit mit Hilfe des LactoCorders. Züchtungskunde 71 (6), 459-472.

11. Gäde, S., Stamer, E., Junge, W., Kalm, E. (2006): Estimates of genetic parameters for milkability from automatic milking. Livestock Science 104, 135-146. https://doi.org/10.1016/j.livsci.2006.04.003

12. Gleeson, D.E., Meaney, W.J., O'Callaghan, E.J., Rath, M.V. (2004): Effect of teat hyperkeratosis on somatic cell counts of dairy cows. International Journal of Applied Research in Veterinary Medicine 2 (2), 115-122.

13. Guler, O., Yanar, M., Aydin, R., Bayram, B., Dogru, U., Kopuzlu, S. (2009): Genetic and environmmental parameters of milkability traits in Holstein Friesian cows. Journal of Animal and Veterinary Advances 8 (1), 143-147.

14. Haghkhah, M., Ahmadi, M. R., Gheisari, H.R., Kadivar, A. (2011): Preliminary bacterial study on subclinical mastitis and teat condition in dairy herd around Shiraz. Turkish Journal of Veterinary and Animal Science 35 (1), 1-8.

15. Hodgson, A.S., Murdock, F.R. (1980): Effect of teat end shapeon milking rate. Journal of Dairy Science 63 (1), 147. 
16. Interbull (1999): Proceedings of international workshop on genetic improvement of functional traits in cattle Breeding goals and selection schemes, Wageningen, The Netherlands. Interbull bulletin 23, 221-223.

17. Lee, D.H., Choudhary, V. (2006): Study on Milkability Traits in Holstein Cows. Asian-Australian Journal of Animal Science 19 (3), 309-314. https://doi.org/10.5713/ajas.2006.309

18. Lojda, L., Stavikova, M., Polacek, J. (1982): Heritability of teat shape and teat end shape in cattle. Acta Veterinaria Brno 51, 9-67. https://doi.org/10.2754/avb198251010059

19. Mein, G.A., Neijenhuis, F., Morgan, W.F., Reinemann, D.J., Hillerton, J.E., Baines, J.R., Ohnstad, I., Rasmussen, M.D., Timms, L., Britt, J.S., Farnsworth, R., Cook, N., Hemling, T. (2001): Evaluation of bovine teat condition in commercial dairy herds: 1 . Non-infectious factors. In Proceedings of the $2^{\text {th }}$ Internacional Mastitis and Milk Quality Symposium NMC/AABP, Vancouver, 347-351.

20. Mein, G.A., Williams, D.M., Reinemann, D.J. (2003): Mechanical forces applied by the teat cup liner and responses of the teat. $42^{\text {nd }}$ Annual Meating of NMC, Fort Worth, Texas, USA, 114-123.

21. Mein, G.A., Reinemann, D.J. (2009): Biomechanics of Milking: Teat - Liner Interactions. ASABE Annual International Meeting Sponsored by ASABE Grand Sierra Resort and Casino Reno, Nevada, June 21 - June 24, 2009.

22. Mijić, P., Knežević, I., Domaćinović, M. (2004): Povezanost muznih svojstava i broja somatskih stanica u mlijeku simentalskih krava. Krmiva 47 (2), 87-92.

23. Naumann, I. (2001): Milchabgabe und Eutergesundheit von Viertelund Gesamtgemelken bei Kühen. Dissertation, Institut für Tierzucht und Tierhaltung der Landwirtschaftlichen Fakultät, Martin-Luther-Universität, Halle-Wittenberg.

24. Neijenhuis, F. (2004): Teat Condition in Dairy Cows. Dissertation, Utrecht University, Faculty of Veterinary Medicine. Ponsen \& Looijen BV, Wageningen, The Netherlands.

25. Neijenhuis, F., Barkema, H.W., Hogeveen, H., Noordhuizen, J.P.T.M. (2000): Classification and longitudinal examination of callused teat-ends in dairy cows. Journal of Dairy Science 83 (12), 2795-2804. https://doi.org/10.3168/jds.S0022-0302(00)75177-0

26. Neijenhuis, F., Barkema, H.W., Hogeveen, H., Noordhuizen, J.P.T.M. (2001): Relationship between teat-end callosity and occurrence of clinical mastitis. Journal of Dairy Science 84 12, 2664-2672. https://doi.org/10.3168/jds.S0022-0302(01)74720-0

27. Neijenhuis, F. (2004): Teat Condition in Dairy Cows. Dissertation, Utrecht University, Faculty of Veterinary Medicine. Ponsen \& Looijen BV, Wageningen, The Netherlands.
28. Ohnstad, I. (2003): Assessing the scale of teat-end problems and their likely couses. $42^{\text {nd }}$ Annual Meating of NMC, Fort Worth, Texas, USA, 128-130.

29. Rensing, S., Ruten, W. (2006): Genetic evaluation for milking speed in German Holstein population using different traits in a multiple trait repeatability model. VIT, Haideweg 1, D-27283, Verden, Germany.

30. Roth, S., Reinsch, N., Nieland, G., Schallenberger, E. (1998): Untersuchungen über Zusammenhänge zwischen Eutergesunheit, Melkbarkeitsparametern und Milchflußkurven an einer Hochleistungsrinderherde. Züchtungskunde, 70, 242-260.

31. Rupp, R., Boichard, D. (1999): Genetic parameters for clinical mastitis, somatic cell score, production, udder type traits, and milking ease in first lactation Holsteins. Journal of Dairy Science 82, 2198-2204. https://doi.org/10.3168/jds.S0022-0302(99)75465-2

32. Shearn, M.F.H., Hillerton, J.E. (1996): Hyperkeratosis of the teat duct orifice in the dairy cow. Journal of Dairy Research 63, 525-532. https://doi.org/10.1017/S0022029900032064

33. Sieber, R.L., Farnsworth, R.J. (1981): Prevalence of chronic teat-end lesions and their relationship to intramammary infection in 22 herds of dairy cattle. Journal of the American Veterinary Medical Association 178 (12), 1263-1267.

34. Singh, V., Singh, V.K., Doley, P., Singh, A. (2014): Association between Teat condition score and Udder health status in dairy bovines. Journal of $\mathrm{Ag}$ riculture and Veterinary Science 7 (5), 09-11. https://doi.org/10.9790/2380-07510911

35. Stádník, L., Františe, L., Bezdíček, J., Ježková, A., Rákos, M. (2010): Changes in teat parameters caused by milking and their recovery to their initial size. Archiv Tierzucht 53 (6), 650-662.

36. Tančin, V., Ipema, B., Hogewerf, P., Mačuhova, J. (2006): Sources of variation in milk flow characteristics at udder and quarter levels. Journal of Dairy Science 89, 978-988. https://doi.org/10.3168/jds.S0022-0302(06)72163-4

37. Taylor, V. (2006): Dairy cow teat condition scoring. Milk quality assurance program Lead/OMAFRA (ministry of agriculture food and rural affairs): Factsheet, 6-19.

38. Tsenkova, R., Atanassova, S., Kawano, S., Toyoda, K. (2001): Somatic cell count determination in cow's milk by near-infrared spectroscopy: a new diagnostic tool. Journal of Animal Science 79, 2550-2557. https://doi.org/10.2527/2001.79102550x

39. Zecconi, A., Hamann, J., Bronzo,V., Ruffo, G. (1992): Machine induced teat tissue reactions and infection risk in a dairy herd free from contagious mastitis pathogens. Journal of Dairy Research 59, 265-271. https://doi.org/10.1017/S0022029900030545 